\title{
RESEARCH OF COMPUTERIZATION AND IMPLEMENTATION OF THE E-PRESCRIPTION FOR INDIVIDUAL PHARMACIES
}

\author{
Elita Ardava ${ }^{1}$, Oskars Onzevs ${ }^{2}$, Ilmars Viksne ${ }^{2}$, Ivars Namatevs ${ }^{2}$ \\ 1- Riga Stradins University \\ 16 Dzirciema str., Rīga, LV 1007, Latvia \\ Ph: +(371) 29167338, e-mail: elita.ardava@inbox.lv \\ 2- School of Business Administration Turiba, Department of Information Technology \\ 68 Graudu St, Riga, LV 1058, Latvia
$\mathrm{Ph}:+(371) 67616358,+(371) 67615520,+(371) 67619460 ;$ fax: +(371) 67619152; e-mail: Oskars.Onzevs@turiba.lv; Ilmars.Viksne@turiba.lv; ivars@turiba.lv

\begin{abstract}
The paper deals with establishment, implementation and development of electronic prescription or e-Prescription in context with e-Health solutions. It includes introduction of a numerous innovative solutions, which are to be committed for data information flow, data management and functionality as well as of establishment of a new feasible communication forms between doctors, patients and pharmacists. The aim of the study is to describe some technical aspects and functionality of implementation of e-Prescription system for medical institutions, patients and pharmacies; and, calculation of the total cost of implementation (TCI) for Latvian individual pharmacies. Several expecting financial aspects, which have encompassed evaluation of TCI, calculating payback time, ROI, NPV, and IRR are to be calculated. On the bases of these financial calculations, the primary investment of implementation of e-Prescription for individual pharmacies and initial costs are determined. Impact on individual parts of TCI with the scope to individual pharmacy size, location, existence or absence of formal information strategy has calculated. According to collected data, research paper shows how proposed electronic system is going to implement among Latvian individual pharmacies.
\end{abstract}

Keywords: electronic prescription, Latvian individual pharmacies, total cost of implementation.

\section{Introduction}

With the advent of information technology pharmacy has been touched with a new paradigm, which is underpinned in 2006 by Introductory Handbook. This handbook is devoted to and emphasized pharmacy practice approach that should be carried out by doctors, patients, and pharmacies. Necessity of new paradigm is pointed out on a Foreword of Introductory Handbook and it can sound as following:

Pharmacists should move from behind the counter and start serving the public by providing care instead of pills only. There is no future in mere act of dispensing. That activity can and will be taken over by the internet, machines, and/or hardly trained technicians. The fact that pharmacists have an academic training and act as health care professionals puts a burden upon them to better serve the community than they currently do.

This new approach has named pharmaceutical care. On the bases of given definition International Pharmaceutical Federation (FIP) gives a key definition of pharmaceutical care. Pharmaceutical care is the responsible provision of drug therapy for the purpose of achieving definite outcomes that improve or maintain a patient's quality of life.

Pharmacists, being effective health care team members, may need skills and attitudes enabling them to assume many different functions. The concept of the "seven-star pharmacist" was first introduced by World Health Organization (WHO) and can be taken up by FIP on 2000 in its general policy statement on Good Pharmacy Education Practice, which should cover such roles: caregiver, decision-maker, communicator, manager, life-long learner, teacher and leader.

According to Introductory Handbook, term researcher is added in it as an eight's function. With the naked eye there can be able to see that, in order to realize pharmacy paradigm, it 
should be necessary to introduce a numerous innovations into practice, which should be entailed by Information and Communications Technologies (ICT). In addition, pharmacist in his everyday work ought to be engage in management, a system, which is complicated to manage.

\section{Concept of e-Prescription}

European Commissioner for Digital Agenda, Neelie Kroes stated [1]: "e-Health is our key to more sustainable healthcare - it's as simple as that. There's literally no other way to pay for and manage the workload our systems will experience in the coming years. And given that eHealth initiatives like telemedicine are leading to a safer, longer and higher quality of life the question isn't whether to invest. The question is - where do I sign up?"

The clear answer would have consisted of establishing interoperable e-Health services for all stakeholders; in which, one certain and main part would be electronic prescription information system (IS), so called e-Prescription.

e-Prescription means a medicinal prescription, i.e. a set of data like drug ID, drug name, strength, form, dosage and/or indication(s), provided in electronic format. This is understood as the prescription of medicines using software, the electronic transmission of the prescription from the Prescriber (the Health Care Professional or Doctor) to a dispenser (e.g., pharmacy or Pharmacist), where the prescription is electronically retrieved, and the medicine is given to the patient (e.g., e-dispensation) and information about the dispensed medicine(s) is reported electronically.

Decision on creating e-Health solutions in Latvia was undertaken into an effect on 17th August, 2005 when e-Health guidelines and related documents having been accepted by the Cabinet of Ministers, issuing an order Nr. 560 which documented "e-Health Guidelines". While another important linked up document named "Architecture of the Information Systems of the Health Sector" describes high level architecture for systems, which have to be ensured the realization of e-Health Program [2].

\section{e-Prescription information flow}

In order to improve the quality of patients' health care, in which one important part should be pharmaceutical care, there are going to be unfolded and maintained Electronic Health Card (EHC) record. There where will be summarized and kept together basic data from all available sources picked up from patient's different medical records into one common data basing information system. Opening patient's EHC medical personal, wherever it would be located will be able to access to patient's data, diseases, diagnoses, diseases tests, vaccines, patents used medicine and more other necessary information for treatment and recovery of the patient health.

e-Prescription [3] means substituting existing documents` flow of the paper format between medical institutions and pharmacist with electronically created documents; therefore, establishing electronic based services for doctors, patients and pharmacists. Accessibility by all parties to the so call drug journal can to be depended from each group before-given priority level.

e-Prescription will be integrated into e-Delivery system [4] as a part of a common centralized data exchange unit, from where medical institutions and pharmacies will be able to connect through their local information system or, for instance, through using WEB portal. As an advantage of this integrated based solution it should right to mention that each patient would be able to get access to his/her health care information as well as to pharmaceutical care information, especially to prescribed drugs. There is behaviorally speaking evidence for creating a new relationships and communication among doctors, patients and pharmacists, which are to be supposing on cooperation and partnership. 
Implementation of e-prescription can be touched with clinical data flow (treatment data), financial information flow and administrative data flow. These information flows [5] should be ensure accomplishment of such a main functions of e-Prescription:

1. Maintenance and distribution of pharmacy goods classificatory for recipes medicine, sold without prescription medicines` and for the medical devices.

2. Reception of the data from Health Payment Centre (HPC) on the rights for reimbursable drugs and the medicine device to be invoiced.

3. Opportunities to modify and added e-Prescription rights from administrative interface.

4. Opportunity among pharmacies to receive information about e-Prescription (based on patients ID) and to be registered e-prescription into the system for prescriptions full or partial hand out, using pharmacies IS or e-Health portal.

5. Opportunity for doctors to prescribe electronic prescriptions using medical institution IS or e-Health portal.

6. Patients and physicians data access rights to checked by EHC system.

7. Payment information of processing of using e-Booking systems financial module.

8. Patients work with their recipes (using e-Health portal) in order to see prescription to be prescribed to patient and patients medical supplies to be received.

\section{e-Prescription functionality}

Introduction of e-Prescription in Latvia and; therefore, its implementation costs, as from pharmacies wholesaler or pharmacies chains till individual pharmacies point of view are closely related of introduction of national e-Health system into one integrated unit. As mentioned before, it provides creating a conceptual development of the e-Health and IS architecture into one unified single national-wide level. That means, having been integrated separate IS sectors together with records of national significance (CSDD, URL, VZD, PMLP etc.) into one integrated IS [2]. Thus, creating a single e-Environment is related to have access to both health care and pharmaceutical care information.

Organization which is responsible for introduction of e-prescription in Latvia is the Centre of Health Economics (CHE) attracting from ERAF budget (2007-2013) 7408000 EUR for the first stage. There will in this first stage be intended to be introduced EHC (1 668000 EUR); health integration platform (941 000 EUR); e-Prescription, e-Appoinment (appointment with a doctor), e-Refer (refer to doctor) (all total 2126000 EUR) [6].

e-Prescription can be used for and getting access to: (1) prescription of the conventional recipe; (2) prescription of the special recipe; (3) information about prescribed medicine within EHC IS; (4) to emergency medicine IS; (5) vigilance reports; as well as (6) business intelligence.

All above mentioned are integrated through Electronic Message Exchange (EME) to ePrescription electronic service. The functionality [6] of the e-prescription is shown on Fig. 1. As can been seen from Fig.1. e-Prescription IS can basically has ensured prescription circulation between doctor, pharmacist and patient. 


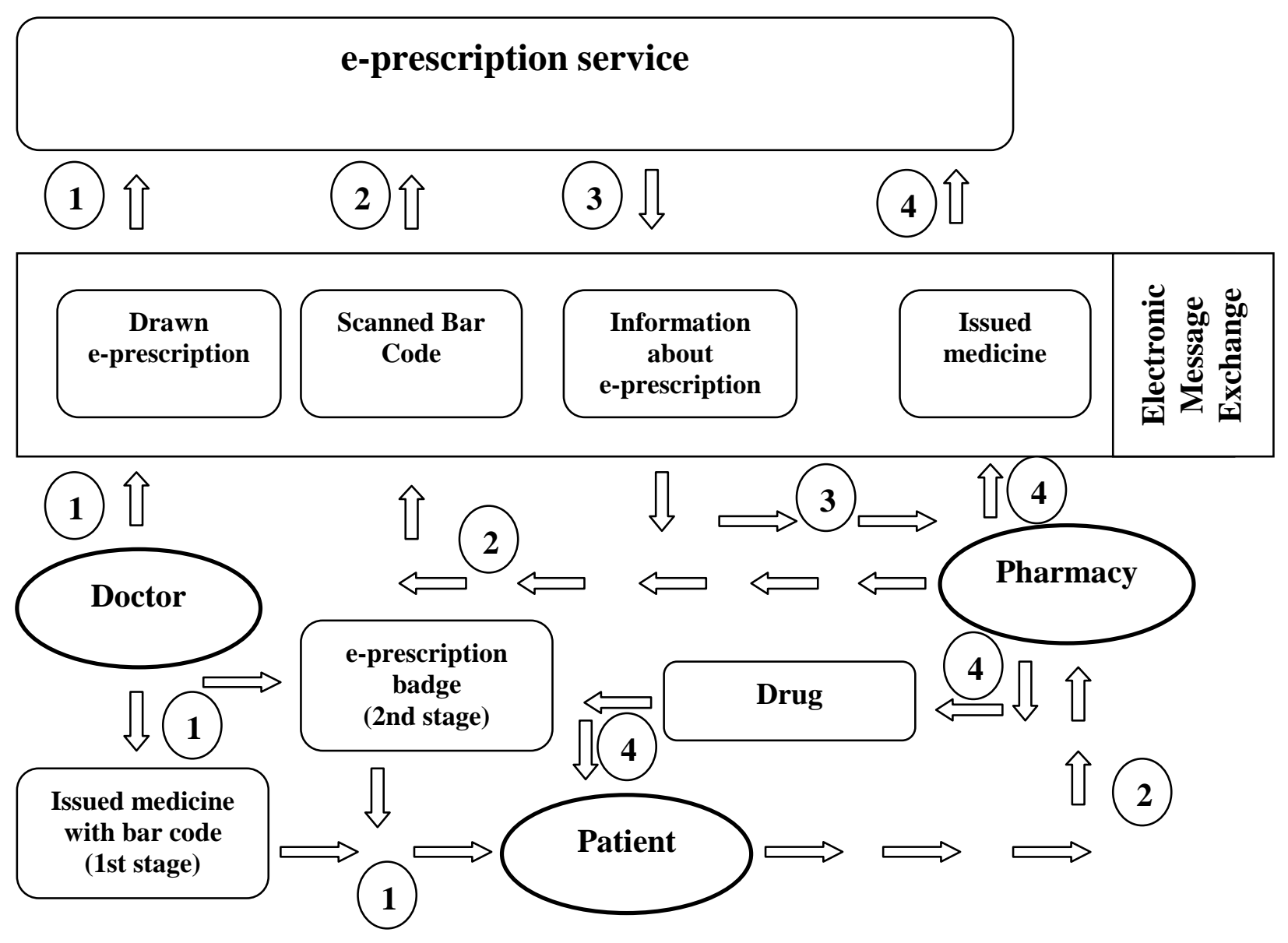

Fig.1. The functionality of the e-prescription

\section{Research object and tasks}

On April 30, 2010, the number of pharmacies are decreased reaching 846: among them 124 pharmacies - pharmacist as one of the owners of the pharmacy; 87 pharmacies - pharmacist as an owner of the pharmacy; 216 pharmacies - pharmacists, assistants of pharmacist, persons with other education or collective body of pharmacy. There are 427 individual pharmacies, which mainly are located in region towns and region small rural areas. These pharmacies are the object of the research, which means, approximately a half from the total number of all Latvian pharmacies. The rest 418 pharmacies belong to the pharmaceutical chains, which are mainly located in 9 cities - Riga, Jūrmala, Jēkabpils, Jelgava, Daugavpils, Liepaja, Ventspils, Valmiera un Rēzekne, as well as, in large regional cities.

Our task was to be sizing up how Latvian regional towns` and regional small rural areas individual pharmacies realizes current provision of law at pharmaceutical care, how the owners of the pharmacies look forward on introduction of ICT for expected introduction of electronic prescription. Comparing to other pharmacies individual pharmacies mainly are located at region small rural areas where the density of the population is low, but the serving area broad.

Problems will be risen for these pharmacies, if small pharmacies should be to financed introduction of pharmacy IS and its further integration to e-Prescription by themselves. Initially, paper format prescription will be anticipating together with electronic prescription. For long term both electronic and paper format might to be economically unprofitable for government. Thus, small pharmacies should be ready to up-to-date their operations. Having 
unable to do that, it can take negative impact on an availability of the medicine and health care at rural region areas. Due to transport problems, not all countryside population will be able to go to the nearest regional city for necessary medicine, So, two main research tasks has been risen on issuing:

1. Performing questionnaire survey, define pharmacies attitude and readiness towards pharmaceutical care.

2. Counting all primary costs, consist with introduction of electronic prescription and possible consequences.

\section{Costs express analysis for ICT systems introduction}

One of the key points of introduction of ICT system for Latvian individual pharmacies is capital budgeting. From the business point of view, the introduction of the new IS ought to have got an additional profit or at least cost decrease for individual pharmacies. Operations around individual pharmacies we cannot evaluate from the business perspective. Calculation on capital budgeting is based on project management and we assumed that ICT system introduction is looking a project.

Once the potential capital budgeting has been identified its evaluation is based on the following methods. First method is to calculate net present value (NPV), which relies on discounted cash flow (DCF) techniques. To implement this approach it should be proceed as follows. (i) Find the present value of each cash flow, including both inflows and outflows, discounted at the ICT systems cost. (ii) Sum these discounted cash flows and this sum is defined as the ICT systems NPV. (iii) If NPV is positive, ICT system should be accepted, while, if the NPV is negative, it should be rejected.

The equation for the NPV is as follows:

$$
N P V=\sum_{t=0}^{n} \frac{C F_{t}}{(1+r)^{t}}
$$

where, $\mathrm{CF}_{\mathrm{t}}$ - is the expected net cash flow at period $\mathrm{t}$, Ls

$$
\begin{aligned}
& \mathrm{r} \text { - is the ICT system`s cost of capital or discount coefficient } \\
& \mathrm{t} \text { - is its life (in years) }
\end{aligned}
$$

Net cash flow at period $t$ is as follows:

$C F_{t}=N I_{t}+$ Dep $_{t}$

where, $\mathrm{NI}_{\mathrm{t}}$ - is net profit at period $\mathrm{t}, \mathrm{Ls}$

Dep $_{\mathrm{t}}$ - depreciation at period $\mathrm{t}, \mathrm{Ls}$

Net profit calculation which is based on gradually table calculation method can be transformed in one common equation where corporate income tax is to consider as a function:

$N I_{t}=N O I_{t}-$ Dep $_{t}-I_{t}-T\left(N O I_{t} ;\right.$ Dep $\left._{t} ; I_{t}\right)$

where, $\mathrm{NI}_{\mathrm{t}}-$ net profit at period $\mathrm{t}, \mathrm{Ls}$

$\mathrm{NOI}_{t}-$ operating profit including depreciation at period, $\mathrm{t}, \mathrm{Ls}$

Dep $_{\mathrm{t}}$ - depreciation at period $\mathrm{t}, \mathrm{Ls}$

$\mathrm{I}_{\mathrm{t}}$ - interest payments at period $\mathrm{t}, \mathrm{Ls}$

$\mathrm{T}\left(\mathrm{NOI}_{t} ; \mathrm{Dep}_{t} ; \mathrm{I}_{\mathrm{t}}\right)$ - corporate income tax at period $\mathrm{t}$ as a function of operating profit, depreciation at period $\mathrm{t}$, and interest payment at period $\mathrm{t}$ in Ls.

Second method is to calculate the ICT system payback time. Third, the return on investment (ROI) and, fourth, internal rate of return (IRR).

Primary investment that anticipates initial costs for hardware and software has been estimated in range from 1500 ,- to 3000 ,- Ls. Calculations is based on the smallest monthly maintenance costs 35 ,- Ls and coefficient of discount 0.05 .

Original calculations show that there are not expected not substantial costs decreases nor revenue increases. In fact, the introduction of the ICT system will not be able to create an 
additional cash flow for individual pharmacies. There are restrictions in legislation in Latvia on issuing the licenses for pharmacies operations` depending from the number of local inhabitants. That is the answer why in rural areas unlike large cities there is only one pharmacy with permanent number of its clients. It is potentially impossible substantially increase a number of its clients. As a result, individual pharmacies are not a unit of business in its normal sense. Thus, the public authorities` decisions in case of introduction of ICT system are important for them.

Calculating capital budgeting there is evaluated individual pharmacies cash flow at ten-year period starting from introduction of the ICT system from ground. It is based on and to be depending from current annual profit (profit before introduction of the ICT system).

If current annual profit does not cover $50 \%$ from primary investment then there is anticipated to take credit from bank at 5-year period with an interest rate from five to $10 \%$. Calculation shown on Table 1 illustrates necessary current profit derived from foregone income for three different groups (for all groups NPV $>0$ ). (j) Foregone income is less than $20 \%$ from total annual profit. Individual pharmacies belonging to this group, whatever is the primary investment, will not touch with problems of introduction of the ICT system. (jj) Foregone income is more than $20 \%$, but less the $50 \%$. Individual pharmacies belonging to this group are under discussion. (jjj) Foregone income is between $50 \%$ and $100 \%$ from annual profit. Individual pharmacies belonging to this group are impossible to introduce ICT system and eprescription, also.

Table 1.

Necessary current profit, grouped, as foregone incomes, after systems introduction

\begin{tabular}{|c|c|c|c|}
\hline \multirow{2}{*}{$\begin{array}{c}\text { Primary } \\
\text { investment, Ls }\end{array}$} & \multicolumn{3}{|c|}{$\begin{array}{l}\text { Current profit, in Ls, if foregone income after system`s introduction } \\
(\mathrm{NPV}>0)\end{array}$} \\
\hline & $\geq 50 \%<100 \%$ & $\geq 20 \%<50 \%$ & $<20 \%$ \\
\hline 1500 & $>650$ & $>1300$ & $>3850$ \\
\hline 2000 & $>700$ & $>1450$ & $>4250$ \\
\hline 2500 & $>750$ & $>1550$ & $>4700$ \\
\hline 3000 & $>800$ & $>1700$ & $>5050$ \\
\hline
\end{tabular}

On the basis of this calculations, there can be predicted that the introduction of the system is not possible at all, if current profit is less than 650,- Ls. Moreover, financially weak individual pharmacies have currently incomplete infrastructure and introduction of the system charges higher investments for them. That means, after 10 year period the new system will create losses and will go bankrupt those pharmacies whose current profit does not today reach $800,-$ Ls. Pharmacies with annual profit, which from $1300,-$ Ls to $1700,-$ Ls are also threatened and introduction of the new system is under consideration. In general, this system could be introduced at pharmacies, whose current profit reaches beyond 3850 ,- Ls. Capital budgeting research has been established a fact that taking a credit from bank marginally influence the data shown on Table 2. Because, in relation to primary investment there are comparatively high operating costs, which annually are 420 ,- Ls or $14 \%$ to $28 \%$ of current investment.

Figure 2 shows sample of 36 provincial towns and countryside pharmacies turnover in Latvian lats from the population of 427 pharmacies. 


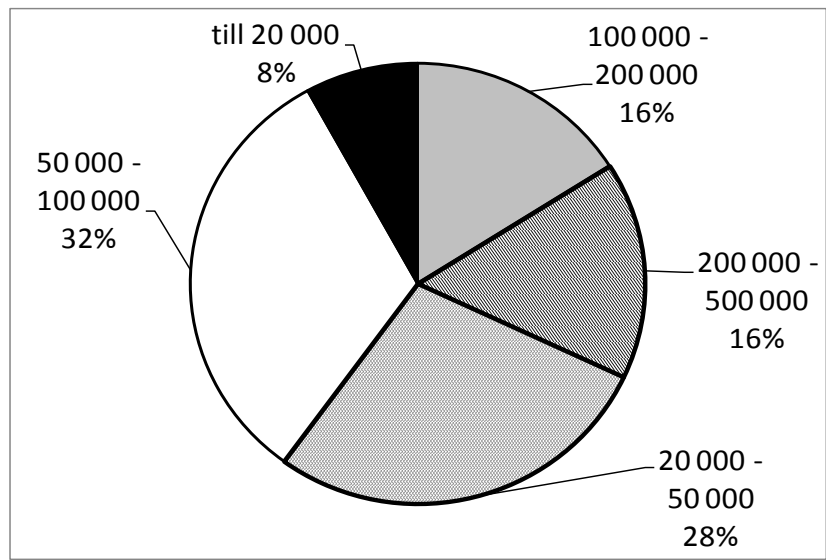

Fig. 2. Provincial towns`and countryside pharmacies turnover in lats

In order to perform an express analysis the data is proportionally taken based on the pharmacies annual turnover, see Figure 2. Having into account express analysis and expert estimate, the potential profit depending from the pharmacies turnover has calculated. This is of course depended from different additional collateral factors: space rent, salary etc. As a result, there has a first approximation of estimated profit depending from pharmacy turnover see Table 2.

Table 2.

Number of pharmacies and estimated profit depending from pharmacies turnover

\begin{tabular}{|c|l|r|c|}
\hline $\mathrm{Nr}$ & $\begin{array}{l}\text { Turnover of pharmacy and } \\
\text { percentage from total } \\
\text { number of pharmacies }\end{array}$ & $\begin{array}{l}\text { Number of } \\
\text { pharmacies }\end{array}$ & Estimated profit \\
\hline 1. & to $20000(8 \%)$ & 34 & Not \\
\hline 2. & $20000-50000(28 \%)$ & 120 & Not \\
\hline 3. & $50000-100000(32 \%)$ & 137 & $3000-5000$ \\
\hline 4. & $100000-200000(16 \%)$ & 68 & $5000-10000$ \\
\hline 5. & $200000-500000(16 \%)$ & 68 & \multicolumn{2}{|c|}{} \\
\hline
\end{tabular}

\section{Conclusions}

From the financial point of view introduction of the system is not possible for $36 \%(8 \%+$ $28 \%$ ) from total number of pharmacies. Moreover, financially weak pharmacies have incomplete infrastructure and introduction of the system charges higher investments to them. These pharmacies cannot increase their situation simply borrowing money from bank, because in relation to primary investment there are existed comparatively high operating costs, which annually constitute 14 to $28 \%$ from primary investment. Planning system would be successfully introduced by pharmacies whose profit reaches 3850 ,- Ls. Problems will be risen for $34 \%$ all registered pharmacies or $68 \%$ individual registered pharmacies in Latvia.

It is quite clear that large half of individual pharmacies will not separately be ready to introduce necessary innovations in their practice. The given research of pharmacies has also shown that large half of pharmacies have only a weak sense on above mentioned innovations and necessity of establishment of the system. After study of the problem, there would be several solutions: joint venture of pharmacies, government support, attraction of EU structural funds etc. 


\section{References}

1. Kroes N. The critical role of cities in making Digital Agenda a reality. Europe Press realases rapid. Speech/10/272. 28.05.2010., pp. 5

http://europa.eu/rapid/pressReleasesAction.do?reference=SPEECH/10/272\&type=HTML

[Accessed 28 February, 2011].

2. VEC e-veselības projektu arhitektūras vadlīnijas.(2010). Rīga: Veselības ekonomikas centrs. 33 lpp.

3. Elektroniskās receptes informācijas sistēma. (2007). Tehniskā specifikācija. 1. sējums. Informācijas sistēmu atbalstāmo pārvaldes procesu analīze. Rīga: Zāļu valsts aǵentūra. 98 lpp.

4. Elektroniskās receptes informācijas sistēmas izstrāde un uzturēšana. (2008). Tehniskā specifikācija. 2. sējums. Informācijas sistēmas attīstības koncepcija. Rīga: Zāḷu valsts aǵentūra. 107 lpp.

5. Behmane D. E-veselības loma veselības nozarē Eiropā un Latvijā, e-veselības projektu virzība. Prezentācija (18.06.2010.). Rīga: Veselības ekonomikas centrs. 20 slaidi.

6. Springge R. Nacionālo e-veselības sistēmu ieviešana. IS Arhitektūras koncepcija un iespējamie risinājumi, Igaunijas pieredze un izaicinājumi Latvijā. Semināra prezentācija (12.01.2011.). Rīga: Veselības ekonomiskais centrs. 25 slaidi. 